\title{
HOME TO WORK? \\ THE EMPLOYMENT EXPERIENCES OF RETURN MIGRANTS
}

\author{
Richard Bedford and Jacqueline Lidgard \\ University of Waikato
}

Late in 1991 the New Zealand Government introduced a points system, similar to that used in Australia, to "encourage a mix of people to settle here, with an emphasis on those who are young and have skills. ... A guaranteed job is no longer a requirement for being approved for residence. Instead, applicants will be assessed against a points system" (New Zealand Immigration Service, 1991,1). The Government's intention is to use a nontargeted points selection system to supplement the skills base of the New Zealand labour force on the assumption that quality migrants will bring capital and energy which will increase domestic demand and provide employment opportunities (New Zealand Immigration Service, 1991, 1).

This policy initiative attracted some critical comment at the time it was introduced into Parliament in July 1991 (PMG, 1991). In general, however, the operation of the points system in New Zealand has not been debated intensively. Recently the Australian equivalent has been subjected to increasing criticism as domestic unemployment has risen. This paper commences with an Australian perspective on the operation of the points system in the context of provision of skilled labour, a perspective which has relevance for the debate about the labour market in New Zealand. The discussion then focuses on a group of international migrants who are beyond the control of points systems and immigration policy in general - New Zealanders returning after a lengthy absence overseas. Their employment experiences in New Zealand are considered and, towards the end of the paper, reference is made to their attitutdes towards current immigration.

In a stimulating address to the Australian Population Association's recent conference, Goddard and Waters (1992), employees in the Department of Employment, Education and Training in Australia, have questioned the efficacy of broad-based skill supplementation through a non-targeted points selection system when there are high levels of domestic unemployment. Using data spanning a decade on the supply of both targeted and non-targeted skilled labour through application of the points selection system, and the demand for skills in the labour market as measured by a monthly skilled vacancy survey, they demons trate that in times of rising domestic unemployment serious oversupply of skills emerges. This is hardly surprising qiven that the points system is essentially supply driven. They note that "the selection mechanism operates in a way which delivers an occupational outcome which is as much a reflection of the supply characteristics of labour markets in migrant source countries as it is of demand in the Australian labour market" (Goddard and Waters, 1992, 15).

They do not question the value of skilled migration per se; indeed they point out that irrespective of general labour market conditions and domestic training output there is always a need for certain types of skills in a dynamic open economy. They suggest, however, that targeted skilled migration, through employer nomination schemes, business skills schemes, and specific labour agreements, which are driven by demand in the local economy, are much more effective at meeting skills needs than the broad-based "population building" components of the Australian immigration programme which are regulated by the points selection system.

If the objective of Government is to use skill supplementation schemes as a mechanism for achieving a larger and more skilled population, then this needs to be articulated clearly within the broader context of a population policy. If, however, the primary objective of the points system is to supply needed skills to the labour market, with a view to stimulating economic activity and providing employment opportunities, then non-targeted skilled migration needs to be responsive to demand in the labour market. Goddard and Waters $(1992,15-19)$ point out that:

Broad-based skill supplementation is, by definition, a scattergun approach, It results in oversupply in many occupations. ... The lack of responsiveness to Australia's economic downturn inherent in the selection process exacerbates unemployment in a range of skilled occupations.... Australia's skill needs, as determined by the market, are well served by targeted skilled migration. ... From a labour market perspective there is no need for supplementation from other migration sources.

\section{A Focus}

The debate about immigration of people with skills rarely takes into consideration one very important dimension of the population flows into a country each year - the citizens who are returning after a year or more of residence overseas. Return migrants are not mentioned by Goddard 
and Waters (1992) in their assessment of the contribution of immigration to the supply of skilled labour. This is hardly surprising given that their focus is on immigration governed by the points selection system, a system which has no relevance for returning Australians. If we are to consider the impact of population flows into a country on the supply of skills in the labour market at any time, however, then some recognition must be given to the contribution made by returning citizens.

During the 1980s New Zealanders returning after more than 12 months residence overseas outnumbered new immigrants. Between 1 April 1981 and 31 March 1991 return migration added 236,000 citizens to New Zealand's population compared with 216,000 new immigrants (Lidgard and Bedford, forthcoming). Certainly there were net losses to the New Zealand citizen population during the decade because, in most years, more New Zealanders left the country than returned. The total net loss of people with New Zealand nationality over the decade was around 100,000 (Bedford, 1992). While a legitimate focus of the research on the migration of New Zealanders is the loss of skills to overseas countries, it is obvious that many who leave do return. Return migrants, in common with new immigrants, seek jobs in New Zealand and their employment experiences are relevant to any debate about the place of broad-based skill supplementation programmes which underlie immigration policies implemented through a points selection system.

This paper examines aspects of the employment experiences of returning New Zealanders using two sources of data. The first is the 1991 Census of Population and Dwellings which permits a population of return migrants to be defined on the basis of birthplace and place of usual residence in 1986. Returning New Zealanders are defined as people who were bom in New Zealand and resident here in 1991, but who were usually resident overseas in March 1986. Some characteristics of this subgroup of international migrants to New Zealand between 1986 and 1991 are compared with the other immigrants who had been born overseas and were resident outside New Zealand in 1986, and a group called residents who were living in New Zealand in 1986 and 1991.

The second source of data is a nation-wide survey of New Zealand citizens who returned to New Zealand in November 1990. This survey was carried out by Lidgard (1992). In this paper some of her findings from two questionnaires are discussed: an initial response by 740 return migrants in March 1991, and 340 replies to a followup survey in September 1991. The survey methodology will not be detailed here; as it has been outlined elsewhere (Lidgard, 1992).

Views of return migrants on the Government's policy of encouraging immigration of young people with skills were sought in the September 1991 survey. An objective here was to assess the extent to which current immigration policy in New Zealand is perceived to be in touch with the reality of returnees' experiences seeking work in the contemporary labour market. Just over 60 percent of the respondents were critical of a policy which is directed at increasing the supply of skilled labour in New Zealand when there is high domestic unemployment, and many returning New Zealanders cannot find satisfactory work.

Before examining more closely some of the views which return migrants have about immigration policy it is necessary to establish some measures of their involvement in the labour force. The next section considers evidence obtained from the 1991 census.

\section{A Macro-Perspective}

The 1991 Census of Population and Dwellings recorded 158,280 people who had been living overseas in March 1986 out of a total resident population aged 5 ycars and over of 3,096,780. These 'immigrants', who had arrived in New Zealand sometime between March 1986 and March 1991, included 50,136 people born in New Zealand ( return migrants) and 108,144 people who had been born overseas (recent immigrants). In total they comprised just over 5 percent of the resident population in March 1991.

The return migrant component, which accounted for just under one-third of the total recent immigrants, was more heavily concentrated in the younger workforce age groups (especially the late 20 s and early 30 s) than the overseas-born recent immigrant component (Figure 1). This distinctive age composition for return migrants has been commented on in several recent studies, especially the work of the former Population Monitoring Group (PMG, 1991; Lowe, 1991). It has particular relevance for the workforce because people aged between 25 and 34 years tend to have high levels of labour force participation.

Return migrants compete directly with residents and recent immigrants from overseas for jobs. In this regard, it is interesting to see how they compared in terms of some basic workforce characteristics in March 1991. It is clear from Table 1 that amongst male return migrants in three of the four age groups shown there was a higher incidence of unemployment than amongst the recent overseas immigrants and the residents. Just under 20 percent of the male return migrants aged between 20 and 24 years stated they were unemployed and seeking work in March 1991 marginally higher than the 19 percent of recent immigrants and 17.7 percent of residents. The gap between the return migrants and the recent immigrants in terms of percentages unemployed was largest in the 25-29 year age group which, as noted in Figure 1, contains a disproportionately large share of immigrants.

In the case of females, the situation was rather different - recent immigrants tended to have higher levels of unemployment than either return migrants or non-migrants (Table 2). It is interesting to note that declared levels of unemployment amongst women who had returned were lower at all ages than those for men, while in the case of 
Figure 1. Age-sex structure, return migrants and recent immigrants, March 1991

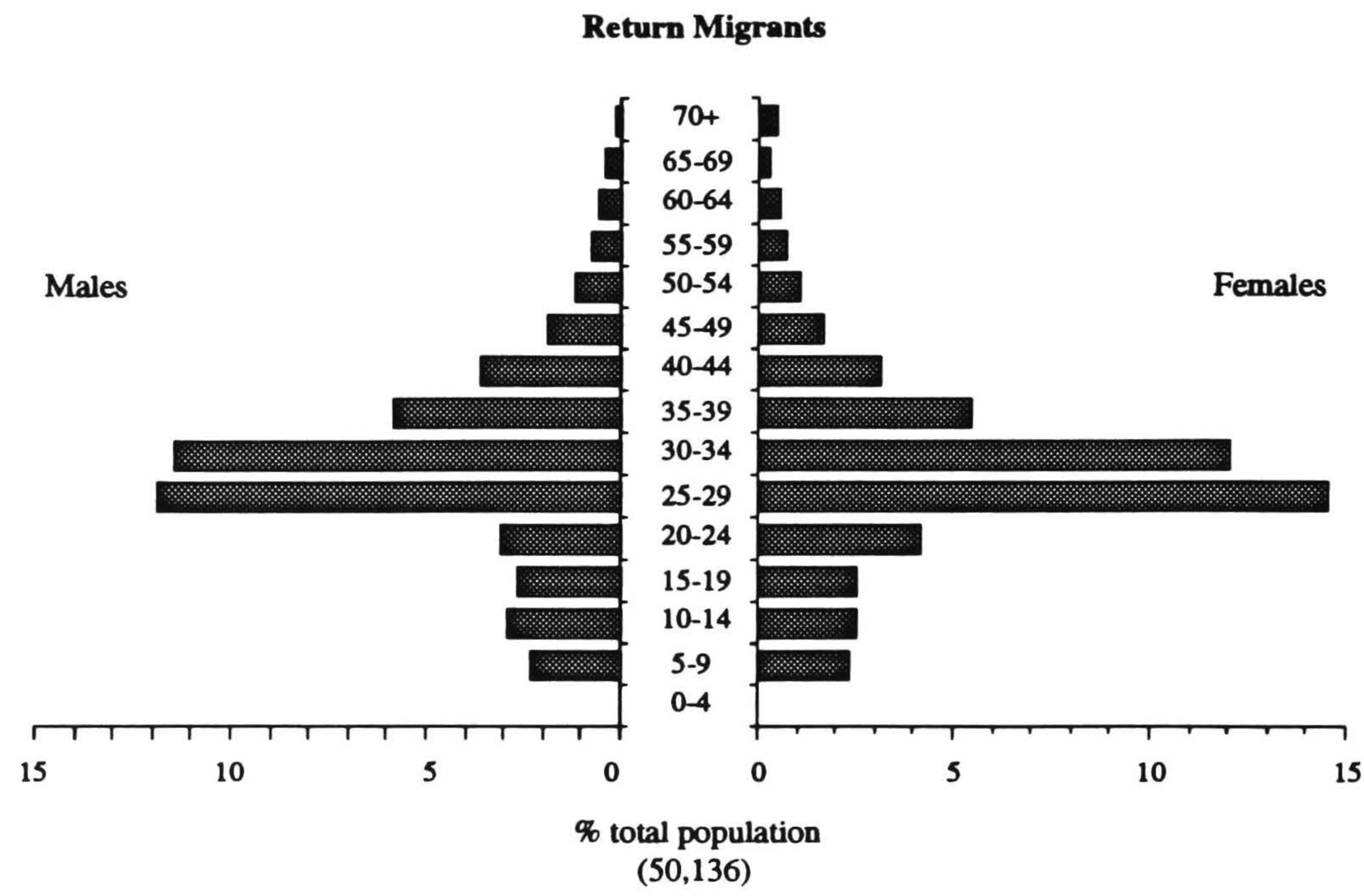

Recent immigrants

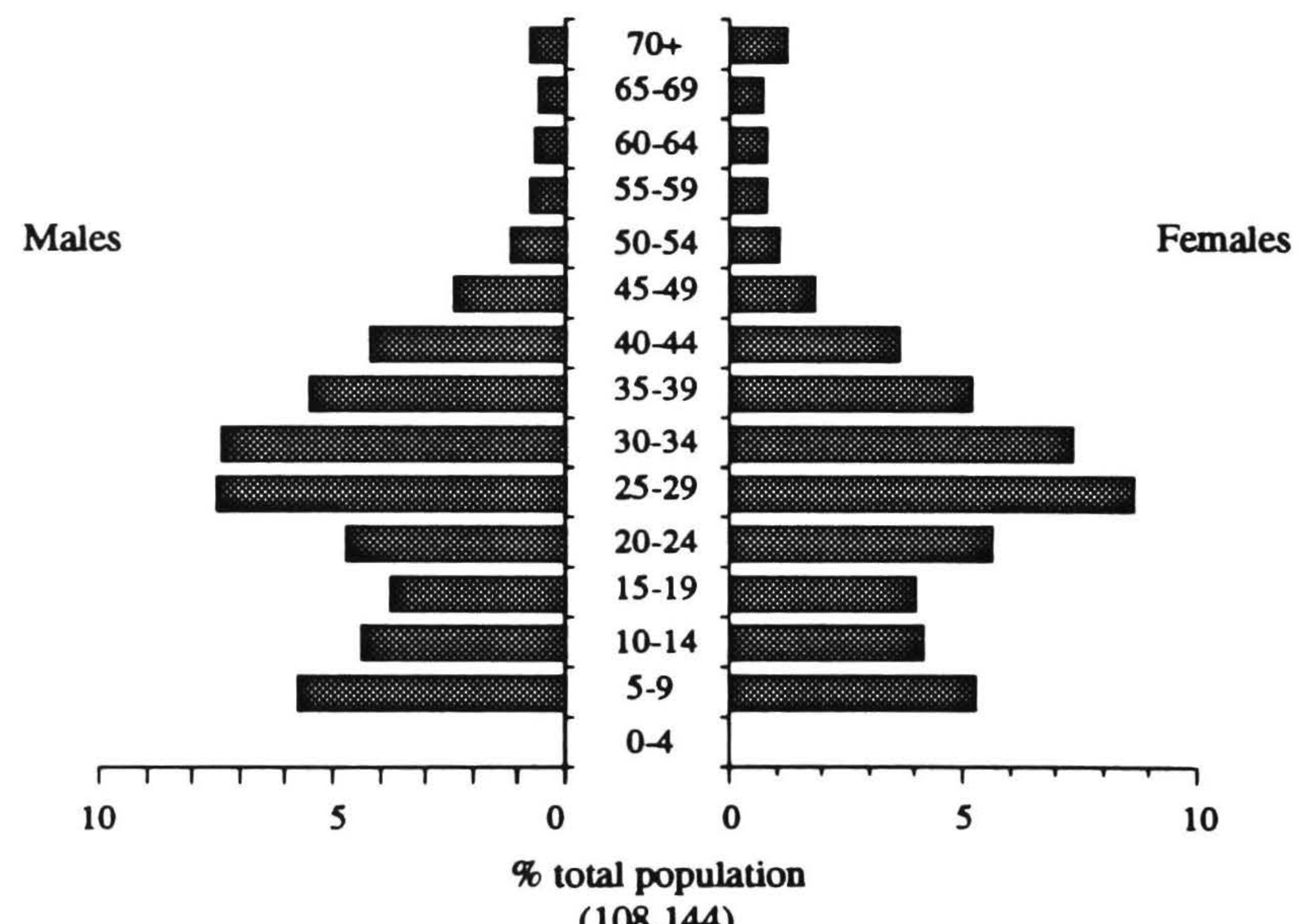

$(108,144)$ 
Table 1. Some characteristics of male return migrants,recent immigrants and residents, March 1991 (percentages)

Group

Unemployed Skilled $\begin{gathered}\text { Characteristica } \\ \text { Unskilled }\end{gathered}$ Tert. Qual. $\quad+\$ 30000$

20-24

Return migration

19.7

18.9

Recent immigration

17.7

47.8

32.9

44.9

11.0

36.5

16.2

Residents

13.8

34.4

12.2

$10.4 \quad 39.6$

13.2

25-29

Return migration

13.6

10.3

53.8

10.1

42.9

38.0

54.8

Residents

11.9

49.6

7.9

56.1

34.5

$\begin{array}{lll}8.2 & 46.6 & 37.0\end{array}$

30-39

Return migration

9.1

58.7

8.2

47.8

51.0

Recent migration

8.7

68.1

5.4

65.2

50.3

Residents

7.7

55.8

6.1

50.6

52.5

\section{0-49}

Return migration

Recent immigration

9.5

57.6

$\begin{array}{ll}6.6 & 54.0 \\ 4.5 & 64.6 \\ 5.9 & 47.1\end{array}$

5.5

47.1

54.8

The characteristics are:

unemployed: unemployed and seeking work

skilled: occupations classed as legislators, administrators, managers, professionals, technicians, associate professionals, trades people.

unskilled: elementary occupations

tert. qual: have a tertiary qualification

$+\$ 30,000$ : annual income over $\$ 30,000$.

Source: Unpublished tables, New Zealand Census of Population and Dwellings, 1991.

recent immigrants the reverse was true. There is obviously some variation in the employment experiences of different groups of immigrants, both on basis of age and gender, and also on the basis of migrant status.

The percentages of the twomigrant groups and the residents in occupations which could be broadly classed as "skilled" and "unskilled" indicated that there was a higher frequency of return migrants in the "unskilled" categories than immigrants or residents for both males and females at all age groups except 20-24 years (Tables 1 and 2). In the case of "skilled" occupations, return migrants were better represented in proportional terms than residents at all ages except the early $20 \mathrm{~s}$. There were higher percentages of recent immigrants in skilled occupations than return migrants aged above 25 years (Tables 1 and 2).
These differences in occupation distribution reflect, in part, the skills which the migrants and residents are bringing to the workforce. A further characteristic which is summarised in Tables 1 and 2 is the percentage of immigrants and residents who stated they had a tertiary qualification. Recent immigrants, both male and female, reported a higher incidence of tertiary training at ages above 25 years, than either retum migrants or residents. This is hardly surprising given the emphasis placed on skills in the immigrant selection process.

In the age groups under 40 years the return migrants had a slightly lower incidence of tertiary qualifications than residents of comparable age and gender (Table 1 and 2). Return migrants, as these can be defined in the 1991 census, were not a better qualified sub-group in the population than residents. That said, however, slightly higher proportions of male return migrants had total annual 
Table 2. Some characteristics of female return migrants, recent immigrants and residents, March 1991 (percentages)

Group

\section{0-24}

Return migration Recent immigration Residents

\section{5-29}

Return migration Recent immigration Residents

\section{0-39}

Return migration Recent migration Residents

\section{0-49}

\section{Return migration} Recent immigration Residents
17.0

19.7

16.5

12.2

12.1

12.1

11.4

\section{9}

11.8

5.4
30.5

23.1

29.8

39.6

45.2

39.7

40.3

46.3

40.1
Characteristic

Unskilled Tert. Qual.
$+\$ 30000$

\footnotetext{
a The characteristics are:

unemployed: unemployed and seeking work

skilled: occupations classed as legislators, administrators, managers, professionals, technicians, associate professionals, trades people.

unskilled: elementary occupations

tert. qual: have a tertiary qualification

$+\$ 30,000$ : annual income over $\$ 30,000$.
}

Source: Unpublished tables, New Zealand Census of Population and Dwellings, 1991.

incomes above $\$ 30,000$ than tended to be the case for either recent immigrants or residents (Table 1). The lowest percentages for males in this income category were found for new immigrants. In the case of females, the situation was reversed: there were higher percentages of recent immigrant females than return migrant or resident females in the $\$ 30,000$ plus income category in most of the age groups shown in Table 2.

These summary statistics indicate that there are some differences, albeit often relatively small, between return migrants, recent immigrants and residents in characteristics related to their participation in the labour force in 1991. Return migrants tend to be experiencing marginally higher levels of unemployment and higher levels of participation in unskilled work than recent immigrants. This is related, in part, to the fact that return migrants had a distribution across New Zealand's rural and urban regions which was very much closer to that for the resident population than the distribution of recent immigrants. The immigrants were concentrated in the main urban areas, especially Auckland and Wellington.

\section{A Micro-Perspective}

Return migration of New Zealanders from Australia attracted considerable media comment during 1990, the year in which the National Government began to extend the pro-active immigration programme set in train by the previous Labour Government. During the year ended 31 March 1991 there was the largest net gain of New Zealand citizens in any year since the return of the troops after the Second World War (Lowe, 1991). The same year saw unemployment continue to rise in New Zealand, and further deterioration in economic conditions in Australia. The out-migration of New Zealanders intending to stay 


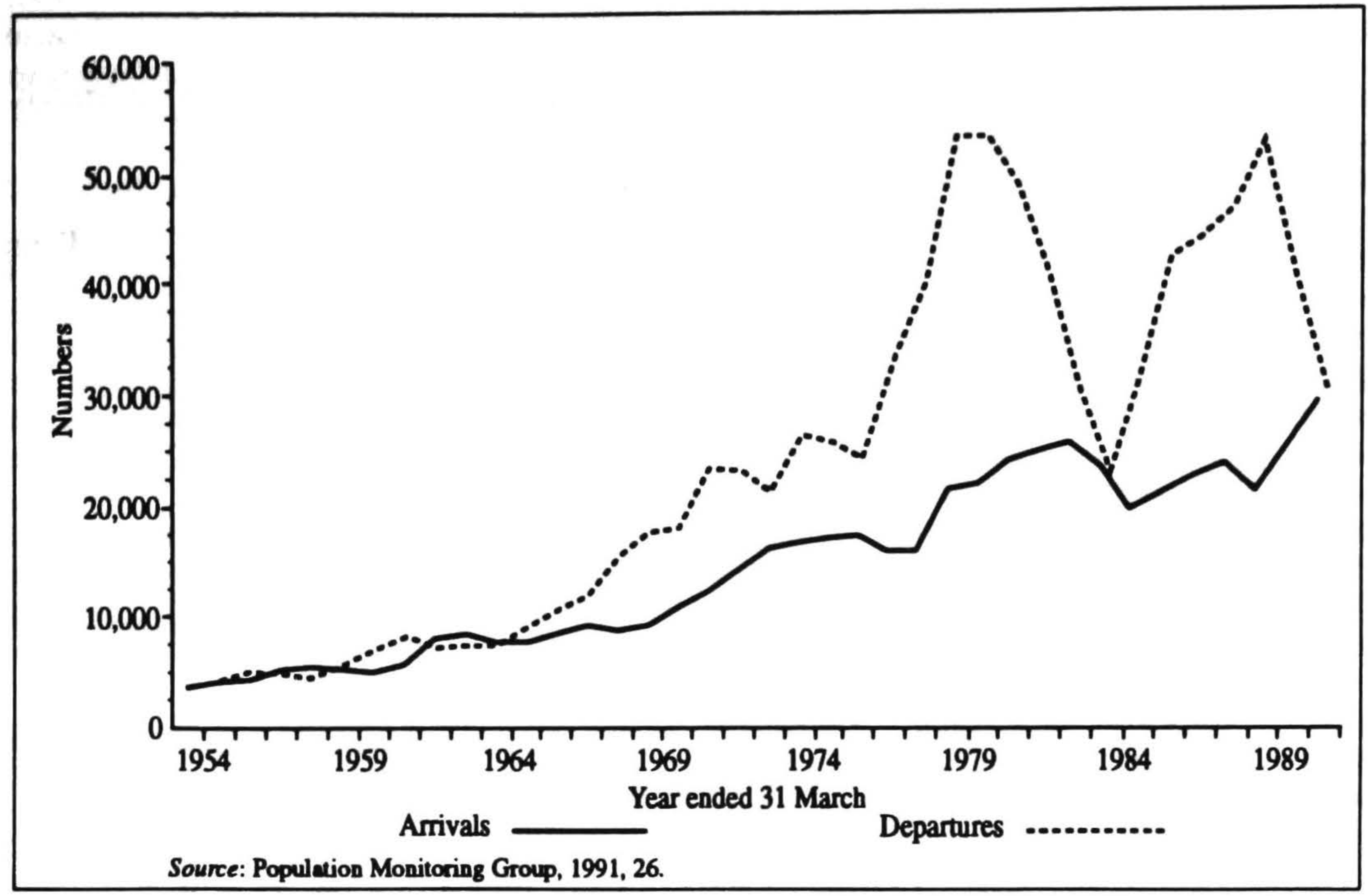

a: Permanent and Long-Term Arrivals and Departures of New Zealand Citizens, April 1953 to March 1991

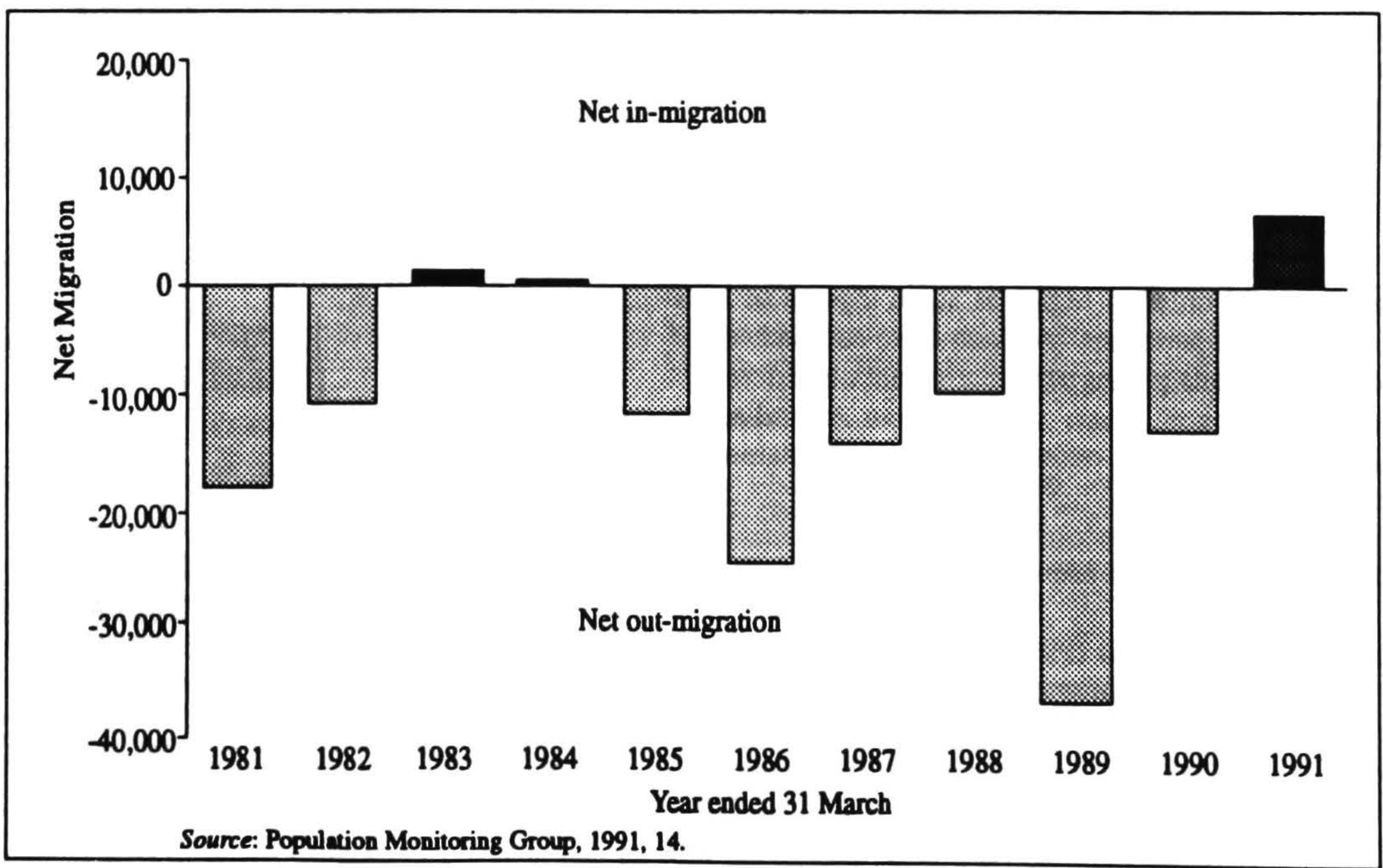

b: Net Migration Gains and Losses, New Zealand Citizens, April 1980 to March 1991 
overseas for 12 months or more fell sharply during the year and this, coupled with a much less dramatic, but still quite marked increase in the numbers of return migrants, produced the largest net gain of New Zealanders since the mid-1940s (Figure 2).

\section{A national survey}

In order to gain a better understanding of an ignored dimension of the migration behaviour of New Zealanders - the return and adaptation to conditions back in their "home" country - at a time when domestic unemployment was high and rising, and immigration policy decisions were likely to increase competition for skilled jobs in the labour market, a national survey of return migrants was organised. This survey required the assistance of the Immigration Service in order to contact all New Zealand citizens aged 15 years and over who had returned to New Zealand in November 1990 after an absence overseas of 12 months or more.

Using the addresses given on cards completed by "permanent and long-term arrivals" in November 1990, New Zealand citizens were invited by the Immigration Service to participate in a return migration study. Approximately 36 percent of the returning New Zealand citizens over 15 years of age in November 1990 agreed to complete a postal questionnaire. This questionnaire was sent out to them in March 1991, and 740 responses which could be used for subsequent analysis were received. There was a follow-up survey of these return migrants in September 1991 which was designed to obtain more information on their employment experiences and adaptation to changed economic circumstances in New Zealand. In this case 340 responses were received. Both the initial sample of 740 respondents and the September group were representative of the November 1990 population of return migrants on a range of variables (Lidgard, 1992; Lidgard and Bedford, forthcoming).

In this section of the paper we draw selectively from the extensive information provided by returning New Zealanders in order to highlight some aspects of their employment experiences. A much more comprehensive analysis of the data, paying particular attention to differences between groups of return migrants from Australia, the United Kingdom and other countries, is contained in Lidgard (1992).

\section{Finding employment in March 1991}

Responses to the March 1991 questionnaire revealed that 83 percent of the return migrants were seeking employment on or soon after their arrival in New Zealand in November 1990. This very high anticipated labour force participation is explained by the fact that the great majority of the return migrants were in their late 20 s and early 30 s - the ages when there are high levels of participation by both men and women in the workforce (Figure 3).
Figure 3. Age-sex pyramids of New Zealand citizen PLT arrivals, April 1990 to March 1991.

Base population November 1990, survey population March 1991

\section{PLT Arrivals, April 1990 to March 1991}

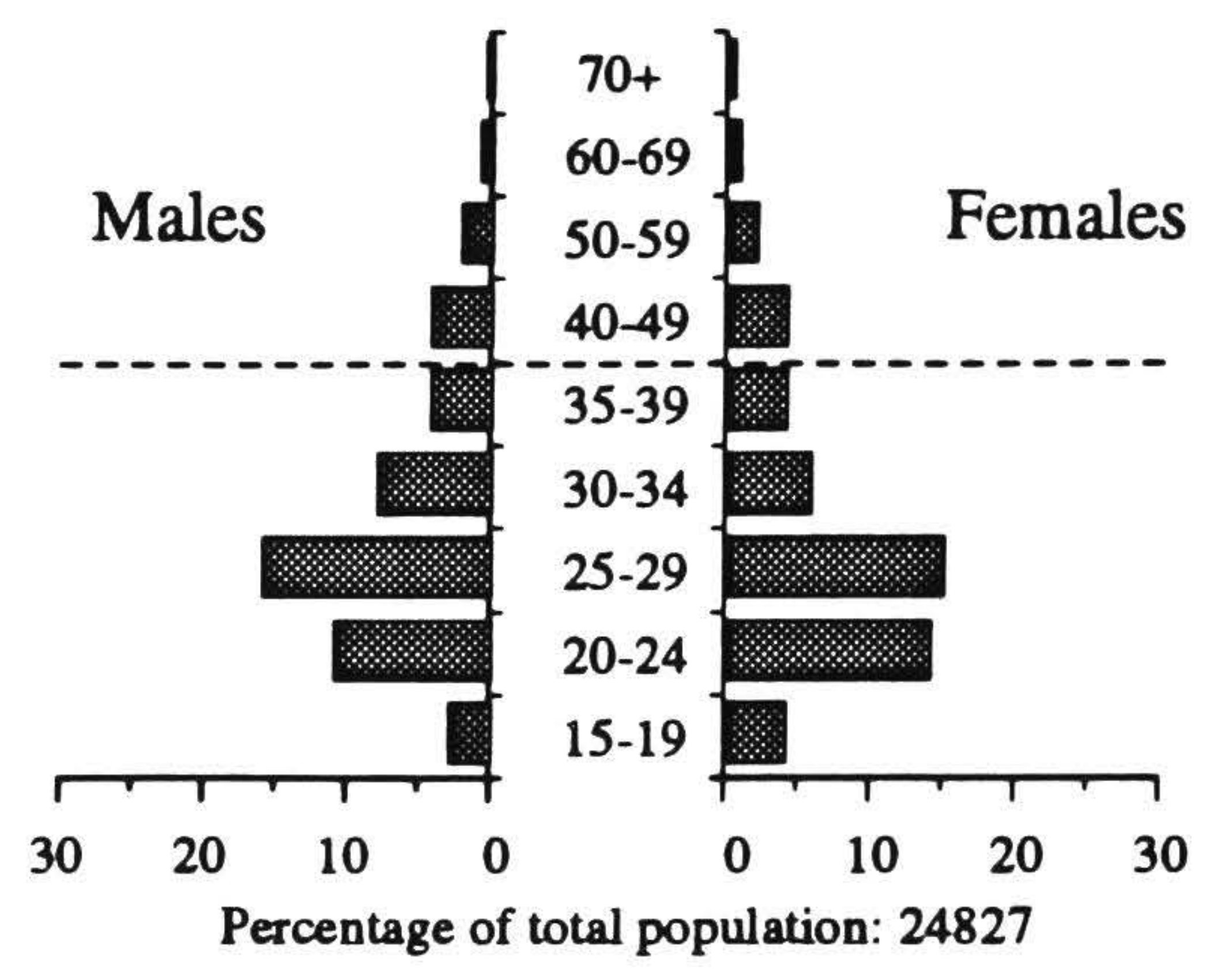

Base Population, November 1990

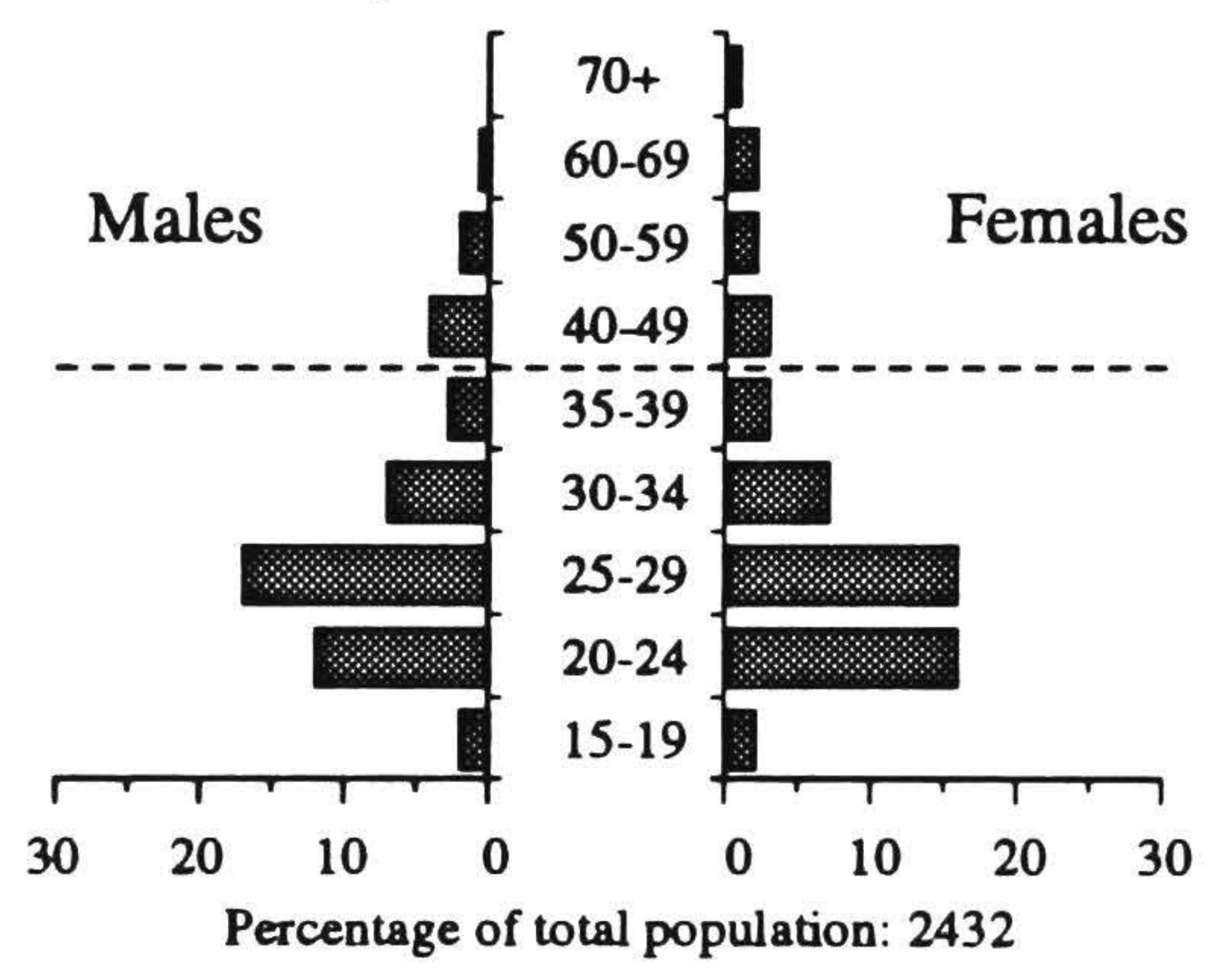

Survey Population, March 1991

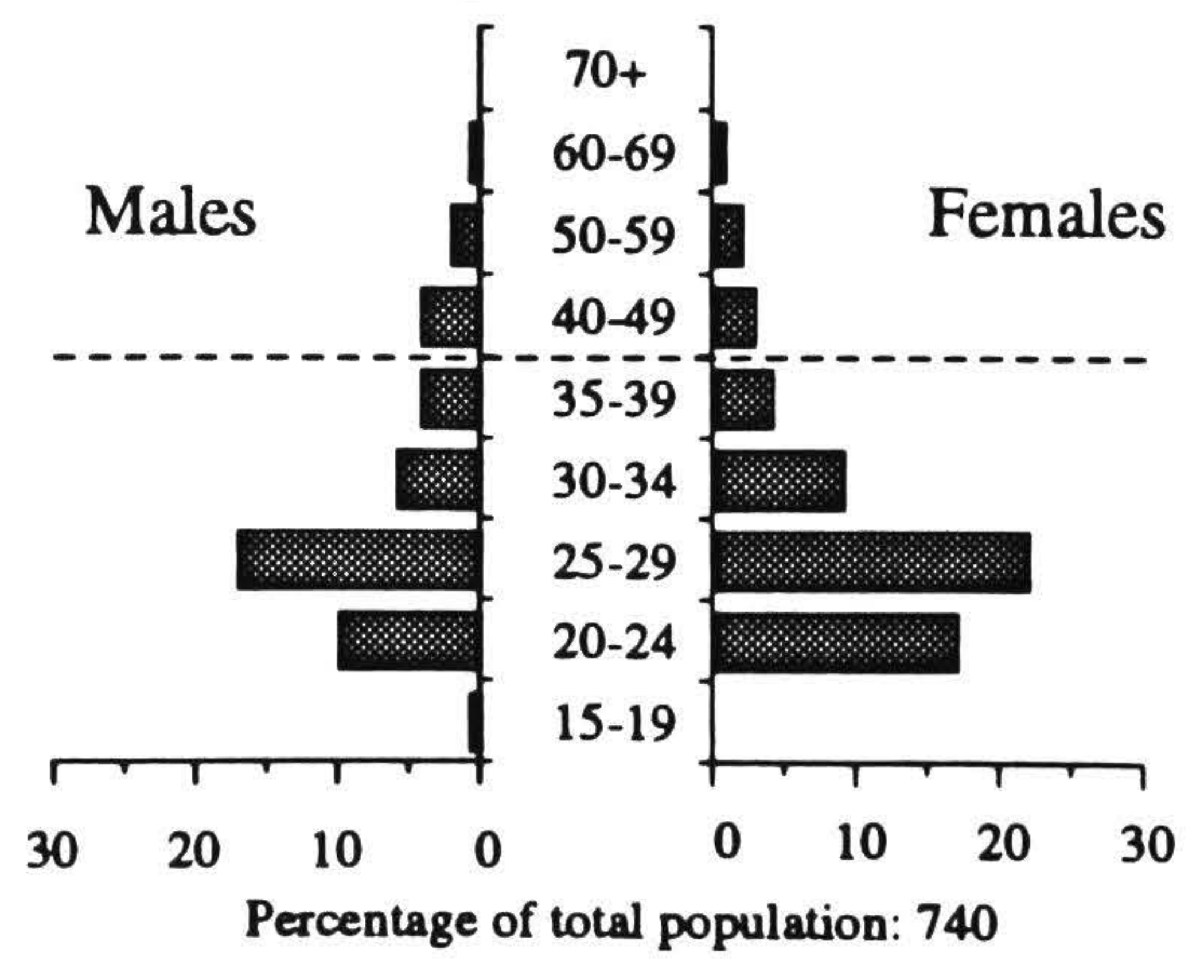


By March 1991 two thirds of those who had wanted work on return in November had found a job. The remainder were still job hunting. Those who had managed to find employment by March 1991 were asked to rate the relative difficulty they had experienced in finding jobs. Of the 351 who responded to this question, 43 percent stated that they had found it easy to gain employment, 37 percent had experienced some difficulty, while 21 percent indicated that they had found it very difficult to find a job.

When broad occupational categories of respondents were taken into consideration, it was found that the occupation group experiencing the greatest degree of difficulty for both men (25 percent) and women (33 percent) included those employed in the clerical, sales, services and related work category (Table 3). The other group of men who had almost as great a degree of difficulty included those in the professional, technical, administrative, managerial and related work category. Those reporting the greatest ease in finding employment were women in the professional, technical, administrative, managerial and related work category ( 52 percent) and both men and women (55 percent and 56 percent respectively) in the primary and secondary production categories (including transport operators and labourers).

A few comments by return migrants in March indicate some of their frustrations with conditions in New Zealand:

Upon my return I was taken aback by the negative attitude which had developed and now prevails in New Zealand. I am disappointed that there is little demand for my experience and expertise and insufficient business confidence for me to become self-employed. I no longer have a sense of belonging, of feeling part of things here in NZ. Consequently it is likely that I will again seek opportunity overseas (40-49 year old man)

Since returning to New Zealand it has taken me five months to get a nursing position. I am a Senior StaffNurse with 8 years of post-graduate experience and reasonably well qualified. My present position

Table 3. Degree of difficulty recorded by those seeking a job between November and March, By Occupation Group and Sex (percentages)

$\begin{aligned} & \text { Degree of } \\ & \text { difficulty }\end{aligned} \quad$ P,T,A,M $\quad$ C,S,S
A,F,P,T

Males

$\begin{array}{lllll}\text { Easy } & 40 & 35 & 55 & 35 \\ \text { Difficult } & 37 & 40 & 31 & 35 \\ \text { Very difficult } & 23 & 25 & 14 & 30\end{array}$

Females

$\begin{array}{lllll}\text { Easy } & 52 & 29 & 56 & 58 \\ \text { Difficult } & 37 & 38 & 25 & 32 \\ \text { Very difficult } & 11 & 33 & 19 & 11\end{array}$

$\begin{array}{lllll}\text { Total nos. } & 127 & 118 & 67 & 39\end{array}$

\footnotetext{
accupation groups are the major groups as defined in the population census: P,T,A,M: Professional, Technical, Administrative and Managerial and Related Workers. C,S,S: Clerical, Sales, Service and Related Workers

A,F,P,T: Agricultural, Animal Husbandry, Forestry Workers, Fisherpersons and Hunters; and Production and Related Workers, Transport Equipment Operators and Labourers. NA,U: Not Actively Engaged; and Occupation Unidentifiable
}

Source: Lidgard $(1992,149)$. 
is only temporary but not by my choice, therefore I am considering returning to London where at least I can get work!! (25-29 year old woman)

Returning to New Zealand in November I had little idea of the extent the economy had deteriorated since leaving. You read the odd newspaper report, of course, but you assume they are exaggerated (25-29 year old man)

The Australian economy was on a down-turn so we took the opportunity to return home thinking we would be no worse off. However, we were very wrong. I have good qualifications and skills but after 6 months I still cannot find suitable employment. There are certainly times when we wished we hadn't come home but we intend to make a go of it now (25-29 year old woman)

Due to the fact that I could not find employment in New Zealand I left and returned to Australia where I am currently employed. I would like to return to New Zealand but what is the point if there is no work and no optimism (20-24 year old man who replied from Australia)

It is disturbing to find the reasons I chose to leave the $\mathrm{UK}$ and return to $\mathrm{NZ}$ are in reality a myth. The standard of living here, work conditions and prices are on a downward spiral. Same reasons I left England could make me leave NZ. In order to get employment in New Zealand I have had to take a substantial grade and wage drop (25-29 year old woman)

\section{Plans for future migration in March 1991}

It was clear from their responses to questions about their return that the reality of being back in a familiar country did not match expectations. One expectation shattered for many returnees was that there would be suitable employment available for them in New Zealand. The employment situation in the early 1990 s was quite different from the situation which had existed at the time many of the respondents had left to travel and/or work overseas.

One question arising from these findings was whether economic conditions in New Zealand early in 1991 encouraged, or appeared to encourage, re-emigration. When the figures for the survey population as a whole were considered, they revealed that 27 percent of the respondents planned to leave New Zealand again for $\mathbf{1 2}$ months or more. Of the remainder, 38 percent were undecided about their residence intentions, while 35 percent stated that they had no plans to leave New Zealand again for 12 months. Reasonably similar proportions of men (28 percent) and women ( 25 percent) stated they were definitely planning future migration, and lack of employment prospects was an important factor explaining these intentions.
I will be leaving $N Z$ when necessary paperwork in order. Left NZ to travel and gain experience. Sold owner-operator business in 1984. Returned NZ 1990. Motor trade not in good shape. Go for position they are not looking for top qualified personnel (40-49 year old man)

Main reason for leaving NZ (again) for Australia is for personal relationship and better job prospects. Haveintention of probably returning to New Zealand in a few years time. Still regard it as home (25-29 year old woman)

Main reasons why I have decided to leave NZ again are lack of opportunities and lifestyle options without bigoted value judgements as compared 10 a city like London (20-24 year old man)

I left for experience but can't settle back in $\mathrm{Ncu}$. Zealand. Everyone is so negative here and II is harder to get ahead - career and financially Overseas was a lot easier for me. I had job satisfaction and good money (25-29 year old woman.

\section{Employment in September 1991}

In September 1991, nine months after the respondents had come back to New Zealand, it was decided to ask them to comment further on their employment experiences and their future migration intentions. An interesting picture emerged from their replies to the question on their personal experience in gaining employment. Of the 340 who returned the September questionnaire 260 (76 percent) were currently employed. Less than half of these people (43 percent) reported that they had found the type of work they preferred. Fifteen percent of those employed had had to take temporary or part-time jobs, even though they were looking for fulltime work, and a small number had become self-employed in an effort to avoid needing a welfare benefit (Lidgard, 1992, 160).

Comments on the personal experiences of obtaining work cited by the September respondents were examined in greater detail to establish which employment category reported the highest percentage in preferred employment. As expected the professional, technical, administrative, and managerial workers were in a better position to obtain work of their first preference, and more in this category were able to take advantage of previous contacts to gain a job upon their return. However, even in this occupational category many had waited months before finding work, and for some the prospects of obtaining work in the profession they desired were slim.

I'm a civil engineer with experience predominantly in construction. I've been looking for work since November 1990. One week ago I took up a position in advertising sales since the likelihood of finding engineering employment seems very small (35-39 year old man) 
I am at present unemployed and have been since returning to New Zealand in November 1990. I am a registered nurse (25-29 year old woman).

After continually looking all over New Zealand [for work] I tried overseas and obtained work in Australia (25-29 year old man replying from Australia)

I left Christchurch [after trying to gain employment for four months] and returned to Sydney where I am now working (20-24 year old man)

\section{Future migration intentions in September 1991}

In spite of numerous gripes about the economy, the employment situation, government policies, and the strong sense of pessimism about future prospects in New Zealand, the proportion of people who intended to leave for overseas destinations had fallen by September 1991. Just over half of those respondents who expressed the intention of leaving in March, and were still in New Zealand in September, had changed their minds (Figure 4). Twenty percent of this group had decided to stay while a third were now undecided. Of those who were undecided in March, half had decided to stay by September, while three-quarters of the respondents who intended to stay in March still had this intention in September (Figure 4).

When the occupational categories of those intending to leave were considered it was found that the highest proportions of prospective leavers were in the primary and secondary production industries, and the "not active" category (Table 4). The smallest proportion was found for the professional, technical, administrative and managerial category which is hardly surprising in view of the fact that return migrants seeking these sorts of jobs had had more success finding work during 1991.

Part of the explanation for the decline in the proportion of returnees planning future migration is undoubtedly the fact that some of those who didnot respond to the September questionnaire had already returned overseas. A small number of the questionnaires received in September came from overseas addresses. A more important reason, however, is the strong attachments to people and places in New Zealand which were emphasised universally by return migrants, and which comprised the most frequently cited reasons for coming home (Lidgard, 1992). In spite of difficulties in the job market New Zealand was perceived by most to far surpass any other country as a place to live. As one young woman (20-24 years) put it: "New Zealand is my home and I love it here. If I leave again it will be
Figure 4. Comparison of intentions for future migration between March and September 1991

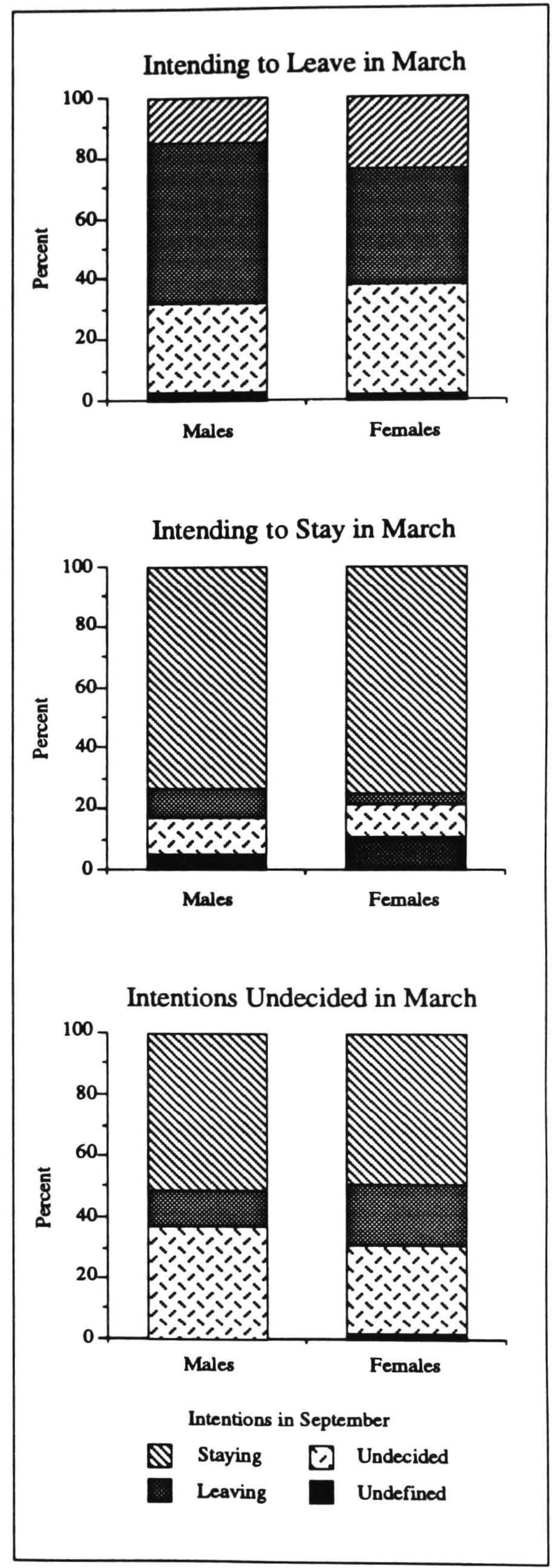


Table 4. Return migrants intending to leave in September by Occupation Group

$\begin{array}{rrrc}\begin{array}{r}\text { Occupation } \\ \text { category }\end{array} & \begin{array}{r}\text { Total } \\ \text { number }\end{array} & \begin{array}{r}\text { Number } \\ \text { leaving }\end{array} & \begin{array}{c}\text { Percentage } \\ \text { leaving }\end{array} \\ \text { P,T,A,M } & 100 & 13 & 13 \\ \text { C,S,S } & 71 & 13 & 18 \\ \text { A,F,P,T } & 47 & 11 & 23 \\ \text { NA,U } & 122 & 28 & 23 \\ & & & \\ \text { Total nos. } & 340 & 65 & 19\end{array}$

Source: Lidgard $(1992,164)$

because of the present unemployment here although I would always return".

\section{Immigration policy and return migration}

Returning New Zealanders, many of whom have tertiary training and specialist work skills gained in New Zealand and overseas, are not all finding it easy to re-enter the workforce. An immigration policy which actively encourages immigration of skilled labour to New Zealand attracted quite a bit of comment from return migrants, especially those who had experienced difficulty in finding work that matched their skills and experience. A widespread feeling amongst the return migrants was that the New Zealand government was not recognising the existence and potential of its own citizens who had come back to work. Two respondents captured the essence of this concern well when they stated:

I have many friends who have recently returned - most of whom have tertiary educations - and about 50 percent are still struggling to find work. I think that the Government are being totally unrealistic if they want to bring more skilled people in .... I think there are many many skilled people in New Zealand who are not being given the opportunity of using their skills. This is very frustrating, and to import more is stupidity (25-29 year old woman)

New Zealand's government policy should be concerned with employment for New Zealanders and current New Zealand residents. It seems preposterous that with nearly 200,000 New Zealanders out of work the Government proposes to exacerbate the situation by pushing more people onto the work-force (40-49 year old man)
Respondents pointed out that New Zealand has to have jobs available for people who are skilled whether they are residents, new immigrants or returning New Zealanders. A major concern was that there were no signals being given by the Government that it was keen to welcome the return of skilledNew Zealanders. Of the 62 percent of respondents in September 1991 who were critical of present immigration policy, 43 percent specifically stated that the Government should be showing more concern for the plight of its own citizens. As a 30-34 year old man put it:

I don't think the Government encourages native bom New Zealanders to return to New Zealand at all, in fact I don't think they have even thought about it for years. Imagine if just half the New Zealanders living abroad were to return home and bring with them their skills and expertise, savings, positive thinking, ideas, dreams, overseas contacts - this country would boom like never before.

\section{Conclusion}

Return migration of New Zealanders, in common with emigration of citizens, is outside the control of Government immigration policy. Officials responsible for the administration of this policy would, no doubt, point out quite legitimately, that it is not up to Govemment to encourage New Zealanders to leave or stay. However, it does seem that return migrants in New Zealand are echoing some of the concerns raised recently in the debate about skilled immigration in Australia. An immigration policy which seeks to increase the population with skills in a country must be in tune with the demand for such skills in the economy.

The argument that new immigrants will generate employment through the creation of businesses, investment, and consumption needs to be put in the rather sobering context of an observation about the potential for job creation to absorb the unemployed. Gregory (1990, cited in Goddard and Waters, 1992) has pointed out that the change in job mix over the last twenty years has reduced the impact of employment growth on the level of unemployment. Whereas in 1966100 new jobs could reduce unemployment by 42 workers, in 1990100 new jobs could reduce unemployment by just 8 workers. This is due to the bias in new job growth towards part-time workers which increase the size of the labour force in response to new jobs rather than reduce the unemployment rate. The trend in job mix, which is producing this reduced impact of economic growth on unemployment levels, is not likely to reverse in the foreseeable future.

In this rather pessimistic context it is appropriate to return to Goddard and Waters' (1992) study of immigration and unemployment of skilled labour in Australia. Their conclusion merits careful consideration by the NewZealand Immigration Service as it plans its targets for skilled immigration under the points system for 1993: 
The lack of responsiveness to Australia's economic downturm inherent in the selection process exacerbates unemployment in a range of skilled occupations. To use [a] boxing analogy, many punches are non-scoring. We conclude that broad based skill supplementation should be seen as a contender in the next round of the immigration title fight. The labour market is best served by a knockout (Goddard and Waters, 1992, 19-20).

\section{Future Research}

Unemployment will continue to be one of the major social and economic issues debated in New Zealand and Australia during 1993, especially in the months leading up to national elections in the latter part of the year. In both countries unemployment will remain at levels which politicians and members of the public consider to be unacceptably high. Inevitably immigration policies will be subjected to close scrutiny in the wider debates about job creation, the supply of skilled workers on the labourmarket, and unemployment of skilled and unskilled labour. The relationship between immigration in general and particular immigration policies and these labour market outcomes is still not well understood, particularly in New Zealand and this implies the need for specific research efforts.

The 1991 population censuses in both countries offer considerable scope for analysis of the employment experiences of different subgroups in the population. Research into these employment experiences needs to recognise that amongstmigrant populations retum migrants will not necessarily have levels of labour force participation, occupation compositions and mixes of skills which replicate those of members of the resident population at similar ages. The diversity of employment experiences amongst both resident and immigrant groups therefore needs to be examined more closely in the context of immigration policies designed to boost skill levels and job opportunities in New Zealand. This sort of research is an integral part of a wide-ranging interdisciplinary inquiry into contemporary and prospective population transformations in New Zealand which is being carried out by social scientists associated with the Population Studies Centre at the University of Waikato.

\section{References}

Bedford, R.D. 1992 Population Pacific Viewpoint 32(2): 121-128

Goddard, B. and Waters, T. 1992 The contender broad-based skilled migration - knock-out or decision on points? Paper presented at the Australian Population Association Conference, 28-30 September 1992

Gregory, R.G. 1990 Jobs and gender. a lego approach to the Australian labourmarket Discussion Paper No
244 ANU Centre for Economic Policy Research, Canberra

Lidgard, J. 1992 Return migration of New Zealanders: a rising tide? Unpublished MSocSc thesis in geography, University of Waikato

Lidgard, J. and Bedford, R.D. (forthcoming) Returning New Zealanders: an ignored dimension of international migration Proceedings of the Sixteenth New Zealand Geography Conference New Zealand Geographical Society, Christchurch

Lowe, RJ. 1991 Supplement to On the move: migration andpopulation - trends and policies New Zealand Planning Council Population Monitoring Group Report No. 6, Wellington

New Zealand Immigration Service 1991 New Zealand's immigration policy Department of Labour, Wellington

PMG (Population Monitoring Group) 1991 On the move: migration and population - trends and policies PMG Report No.6, New Zealand Planning Council, Wellington 